plains, "we will be able to answer questions like whether streamflow during storms is coming from recent rainfall flowing into the stream quickly, or if it's coming from shallow runoff moving down hillsides and into the channel through the subsurface, or whether the new rainfall is pushing out old water from deep in the fissures between the rocks."

Jeff Brown, manager of the station, is confident that Sagehen can play a complementary role to other Tahoe-based research. "Sagehen Creek and Lake Tahoe are both part of the Truckee River wa-

tershed," he notes, "yet here researchers can do manipulative studies that often can't be done within the Tahoe Basin itself. Research here will have impact throughout the Sierra and across the country."

For more info:

http://sagehen.ucnrs.org/index.html http://nrs.ucop.edu/Transect-Sagehen.htm.

\title{
Weed control helps prevent erosion into Lake Taboe
}

$\mathrm{L}_{\mathrm{p}}$ ake Tahoe is currently the focus of numerous \lrcorner projects aimed at halting further degradation of its famed water clarity and quality, but historically, invasive weeds have received little attention.

Current research suggests that growth of algae in the lake is fueled by inputs of phosphorus associated with sediment runoff. "The expansion of tap-rooted perennial weeds, especially in riparian areas, can accelerate erosion rates," says Wendy West of UC Cooperative Extension in El Dorado County. "Weeds also have a deleterious effect on recreation, aesthetics and habitat." West is co-coordinator of the Lake Tahoe Basin Weed Coordinating Group, a broad, interagency effort that began meeting in January 2002 to identify, map and control invasive weeds.

The Lake Tahoe Basin is a classic example of a region where weed spread pressure is high, due to its bistate border location, historical escaped ornamental populations, and the seasonal influx of tourists, West says. The lake spans two states and five counties, with differing regulations governing pesticide use.

In 1998, after locating a single perennial pepperweed (Lepidium latifolium) plant growing on a roadside in Incline Village, the University of Nevada Cooperative Extension (UNCE) mounted a public education campaign to identify and eradicate other populations.

To build bistate support for perennial pepperweed management, a series of meetings was convened that included major land-management agencies, the Tahoe Regional Planning Agency, the Lahontan Regional Water Quality Control Board (LRWQCB), city and county representatives, volunteers and others stakeholders. With approval from LRWQCB and private landowners, chlorsulfuron was applied to infestations away from water by certified pesticide applicators between 1999 and 2001, with excellent results.

By 2001, however, it was clear that perennial pepperweed was not the only invasive weed threat-

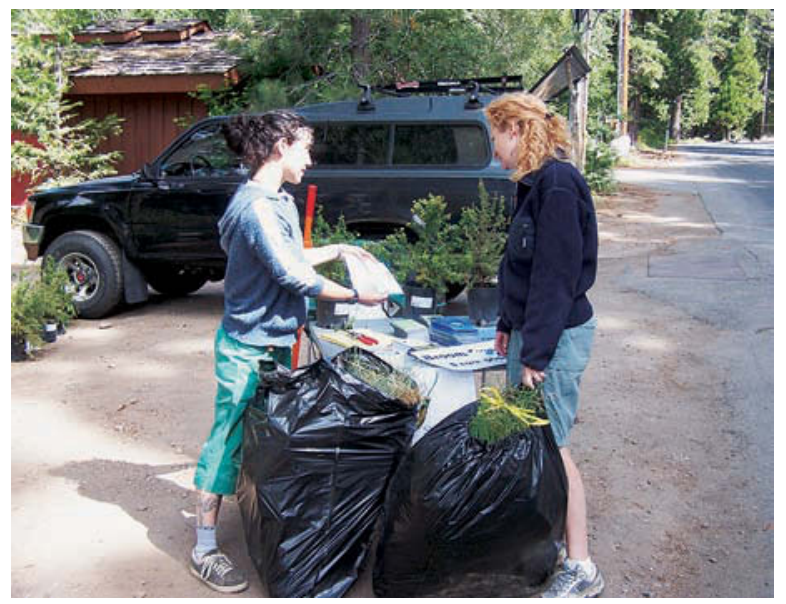

Kim Melody of the Lake Tahoe Basin Weed Coordinating Group (left) provides a resident of the Dollar Point area with alternate landscaping plants to replace invasive Scotch broom removed from her yard.

ening the Tahoe Basin. At the request of the U.S. Forest Service, the weed-coordinating group was formed in 2002 with a 5-year memorandum of understanding. More than 20 invasive species are currently on its "weeds of concern" list, including yellow starthistle (Centaurea solstaitialis), Eurasian watermilfoil (Myriophyllum spicatum) and curly pondweed (Potamogeton crispus).

The group's activities include monitoring, prevention and eradication campaigns, and public outreach and education. For example, in 2005 the group launched a campaign against Scotch broom (Cytisus scoparius), which has roots that fail to stabilize soil. Last summer, area residents traded in Scotch broom plants for free replacements of more acceptable noninvasive landscaping plants.

"The best way to eradicate and control weeds is to prevent their introduction and establishment," says Susan Donaldson, UNCE water quality and weed specialist and co-coordinator of the weed group. 